\title{
Climate change can affect the spatial association between stingless bees and Mimosa scabrella in the Brazilian Atlantic Forest
}

\author{
Cesar A. Marchioro ${ }^{1}$, Valdeir P. Lima ${ }^{1}$, Cinara R. Sales ${ }^{2}$ \\ ${ }^{1}$ Postgraduate Programme in Agricultural and Natural Ecosystems, Department of Agriculture, Biodiversity and Forests, \\ Federal University of Santa Catarina, Campus Curitibanos, Curitibanos, Santa Catarina, Brazil \\ ${ }^{2}$ Bahia State University, Campus Barreiras, Barreiras, Bahia, Brazil
}

Received 24 April 2019 - Revised 15 January 2020 - Accepted 21 February 2020

\begin{abstract}
The species-specific responses to climate change can result in discordant range shifts, leading to changes in associations among species. In this study, we tested whether climate change can affect the spatial association between the plant Mimosa scabrella and the stingless bees Melipona quadrifasciata anthidioides and M. quadrifasciata quadrifasciata. Ecological niche models were used to predict current and future species distributions using intermediate (RCP 4.5) and high (RCP 8.5) greenhouse gas emission scenarios. Our models projected a pronounced reduction in climatically suitable habitats available for the studied species and identified a species-specific response to climate change. As a result, the models estimated a drastic reduction in the spatial association among species of up to $94 \%$ in the coming years, revealing that climate change may affect species interactions.
\end{abstract}

\section{biotic interaction / ecological niche modelling / Melipona / pollination / spatial association}

\section{INTRODUCTION}

The Earth's climate is projected to exhibit relatively rapid changes in temperature and precipitation regimes throughout this century as a result of the increase in greenhouse gas emissions from human activities into the atmosphere (IPCC 2014; Knouft and Flicklin 2017). These changes may cause severe impacts on biological communities and ecosystem functioning (Pecl et al. 2017), considering that species are affected by climate in

Electronic supplementary material The online version of this article (https://doi.org/10.1007/s13592-020-00753-6) contains supplementary material, which is available to authorized users.

Corresponding author: C. Marchioro, cesmarc@gmail.com

Manuscript editor: Alexandra Klein many ways such as changes in species distribution, relative abundance within species ranges and subtle shifts in activity timing and microhabitat use (Williams et al. 2008; Bates et al. 2014). In fact, there is a rich body of evidence showing that climate change is already impacting biodiversity through modifications in species richness and composition (Pecl et al. 2017).

Given that species are unlikely to share identical sets of environmental requirements, the responses to a given combination of biotic and abiotic factors tend to be specific (Harrington et al. 1999). These specific responses to environmental factors can result in discordant range shifts in a climate change scenario, leading to phenological asynchrony and spatial mismatch among species that currently interact. The effects of climate change on species interactions across time have been examined for a range of taxa, such as shifts 
in the relative timing of host-plant and herbivore phenologies and increase in phenological asynchrony between spring green-up and arrival of migratory birds (Harrington et al. 1999; Mayor et al. 2017). Similarly, fossil records show considerable instability in spatial associations among species, suggesting that modern assemblages have no long-term history in the Quaternary (Harrington et al. 1999).

Changes in biotic interactions resulting from climate-driven species redistribution may compromise ecosystem services they provide and, as a consequence, affect economic development and human well-being (Pecl et al. 2017). This is especially relevant for plant-pollinator interactions (Hegland et al. 2009), particularly bees, given the key role they play in food production and forest maintenance. More than $90 \%$ of the major crops worldwide depend on pollinators (Klein et al. 2007), an important ecosystem service responsible for increasing global production by US\$ 235-577 billion dollars annually (Lautenbach et al. 2012). Similarly, most angiosperm species rely on insects and other animals, rather than wind, for reproduction (Memmot et al. 2007), a biotic interaction that plays a significant role in maintaining the functional integrity of terrestrial ecosystems (Ollerton et al. 2011).

In this study, we examined the interaction between Mimosa scabrella Benth. (bracatinga) and the stingless bees Melipona quadrifasciata anthidioides Lepeletier and Melipona quadrifasciata quadrifasciata Lepeletier to assess how range shifts resulting from climate change may affect species association in geographic space. Mimosa scabrella is widely distributed mainly in the southern and south-eastern portion of the Brazilian Atlantic Forest (Flora do Brasil 2018) and, as a pioneer species, plays a key role in ecological succession by providing adequate microhabitat conditions for shade-tolerant trees and food resources for insect pollinators (Luz et al. 2010; Siminski and Mazuchowski 2014). Also, bracatinga timber is used commercially for energy production and in the construction industry (Lunelli et al. 2016). On the other hand, M. q. anthidioides and M. q. quadrifasciata provide important pollination services and produce highly valued honey used by smallholders as additional income (Slaa et al. 2006; Bispo dos Santos et al. 2009). The interaction of M. scabrella with the stingless bees is well reported in the literature. Studies have demonstrated that $M . q$. quadrifasciata and M. q. anthidioides are important visitors feeding on nectar and pollen of bracatinga (Ramalho et al. 1989; Sobierajski et al. 2006; Oliveira-Abreu et al. 2014; Nascimento et al. 2015), besides being one of its pollinators (Catharino et al. 1982).

Ecological niche models (ENMs) have been widely used in studies involving projections of climate change effects on species distributions. In this study, ENMs and Geographic Information System (GIS) analyses were employed to test whether climate change can affect the spatial association between bracatinga and stingless bees as a consequence of dissimilar range shifts resulting from species-specific responses to climate.

\section{METHODS}

\subsection{Occurrence records}

Overall, 340, 63 and 71 occurrence records were gathered for M. scabrella, M. $q$. anthidioides and Mq. quadrifasciata, respectively, using the literature and the online databases Global Biodiversity Information Facility (GBIF) and SpeciesLink. All occurrences were analysed in order to remove the records outside the known distribution range of the species based on information obtained from the online databases Flora do Brasil (2018) for M. scabrella and Moure's Catalogue for the stingless bees.

\subsection{Model predictors}

Elevation data and nine bioclimatic variables obtained from the WorldClim database at the resolution of 5 arc-minutes (Hijmans et al. 2005) were used in the modelling process as follows: annual mean temperature (Bio1), temperature seasonality (Bio4), maximum temperature of warmest month (Bio5), minimum temperature of coldest month (Bio6), temperature annual range (Bio7), annual precipitation (Bio12), precipitation of wettest (Bio13) and driest months (Bio14) and precipitation seasonality (Bio15). These variables 
were selected because they represent temperature and precipitation conditions that are known to constraint species occurrence. We also used the bioclimatic variables projected for 2050 and 2070 based on the scenarios of greenhouse gas emission RCP 4.5 and RCP 8.5 representing intermediate and high levels of gas emissions (Meinshausen et al. 2011) derived from the fifth Intergovernmental Panel on Climate Change assessment report (AR5) of the United Nations (IPCC 2014). In order to reduce the uncertainties associated to future prediction, climate data was obtained for five different Global Circulation Models (GCMs): CCSM4 (Community Climate System Model), HadGEM2-ES (Hadley Center Global Environment Model version 2 Earth System), MIROC5 (Model for Interdisciplinary Research on Climate), MRI-CGCM2.3.2 (Meteorological Research Institute, Japan) and BCC-CSM1.1 (Climate Center Climate System Model). Consensus maps for each species, year and climate change scenario were generated through averaging the final models.

\subsection{Modelling approaches}

Ecological niche models were developed using the maximum entropy algorithm implemented in the software MaxEnt version 3.3.3.k. MaxEnt is a machine learning algorithm that uses presenceonly data to estimate species distribution based on occurrence data and environmental predictors (Phillips et al. 2006). The development of models with appropriated levels of complexity is critical to generate reliable future predictions. We approached model complexity using the following procedures: (i) spatial filtering of occurrence records to avoid spatial autocorrelation; (ii) reduction of the number of predictors by an a priori selection of uncorrelated variables based on their biological significance (Rodda et al. 2011), (iii) delimitation of the study area based on ecological criteria, such as biomes or climate zones (Fourcade et al. 2014; Hill and Terblanche 2014) and (iv) evaluation of the best configuration of MaxEnt parameters with tuning experiments using different combinations of feature classes and regularization multiplier values (Morales et al. 2017).
In agreement with previous studies (Zwiener et al. 2018), the occurrence records were submitted to a spatial filtering (Brown et al. 2017) delimiting a minimum distance of $20 \mathrm{~km}$ between each occurrence for $M$. scabrella, and of $2 \mathrm{~km}$ for the stingless bees based on the flying capacity of the genus Melipona (Araújo et al. 2004). Briefly, a distance matrix was calculated, then the first occurrence point in the list was removed, and the table of distances were re-evaluated until all points are removed at the specified distances. This procedure reduced to 141, 63 and 70 the number of unique records for M. scabrella, M. q. anthidioides, and $M$ q. quadrifasciata, respectively (Figure 1). Also, the predictors were submitted to a Pearson's correlation test to ensure the lack of multicollinearity among them. The variables showing high correlation $(r>$ 0.85 ) were excluded from the modelling process (Elith et al. 2010), and in this case, preference was given to those variables with higher biological significance (Elith et al. 2010). The biome where the species occur was used to delimit the study area and train the models. When occurrence records were recorded only in the margins of the biome, only a portion of this biome was used to delimit the study area (Fig. S1). Maps of the Brazilian biomes were obtained from the Brazilian Institute of Geography and Statistics (www.ibge.gov.br).

Additionally, 15 models for each species were generated using different MaxEnt settings. The feature classes (i.e. a function of an environmental predictor) and the regularization multiplier values are known to affect both complexity and performance of the models generated with MaxEnt (Merow et al. 2013; Radosavljevic and Anderson 2014; Morales et al. 2017). Linear (L), quadratic $(\mathrm{Q})$, product $(\mathrm{P})$, hinge $(\mathrm{H})$ and threshold $(\mathrm{T})$ feature classes can be used in MaxEnt, and the selection of individual features for each predictor is based on their contribution to model fitting using a regularization coefficient $\beta$ (Phillips et al. 2006; Merow et al. 2013). The value of this regularization coefficient can be changed by multiplying it by a userspecified constant named regularization multiplier. In this study, five different combinations of feature classes (L, H, LQ, LQH and LQHPT) and three regularization multiplier values (1, 3 and 5) were tested. All occurrence records were used to build these models and the output format was set as raw. 


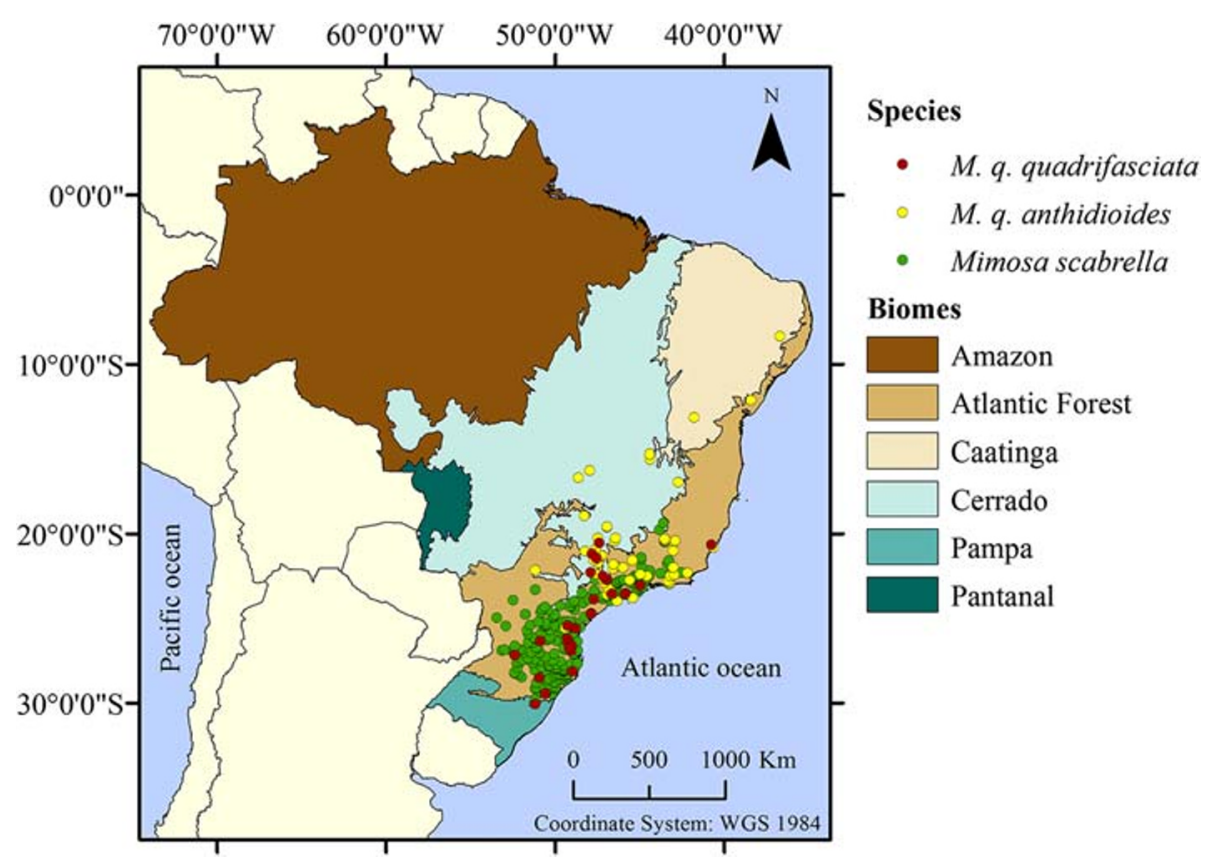

Figure 1. Occurrence records obtained from the literature and the online databases Global Biodiversity Information Facility and SpeciesLink for Mimosa scabrella, Melipona quadrifasciata anthidioides and M. q. quadrifasciata in the different Brazilian biomes.

\subsection{Model evaluation and selection}

The corrected Akaike information criterion (AICc) was used to compare and select the best model for each species. AICc provides information on the relative quality of the models based on their goodness of fit and number of parameters. The lower the AICc values, the better and less complex are the models. The best models selected for each species were ran using $80 \%$ of the occurrence records for training, and the remaining ones were used for the test, with the replicate run-type setting as subsample with 100 replicates. The performance of the models was evaluated using the area under the curve (AUC) of the receiver-operating characteristic (ROC), which assesses the ability of the model to discriminate between omission versus commission errors (Fielding and Bell 1997). AUC values vary between 0 and 1 ; while values closer to 0.5 indicate that the model does not perform better than random, values closer to 1 indicate high performance (Radosavljevic and Anderson 2014).

\subsection{Quantifying changes in spatial association between species}

Distribution shifts due to climate change were assessed through comparison of current and future distributions using binary maps generated with the maximum training sensitivity plus specificity logistic threshold (MSST). This procedure identifies the regions where the model predicted expansion, contraction and/or no change in the species distribution range. A centroid analysis was performed to assess the direction and magnitude of changes through time. This analysis reduces species distributions to a single central point and creates a vector file connecting current and future centroids. Additionally, maps of climate anomalies demonstrating the location and intensity of the projected changes were generated for the most important bioclimatic variables for each species.

Threshold-dependent and thresholdindependent metrics were used to assess the changes in spatial association between bracatinga and the stingless bees. As threshold-independent metric, niche overlap analysis was applied to 
compare the similarity between ecological niche models in space for M. scabrella and stingless bees for the present conditions and then compared with that estimated for the future climate scenarios. This analysis measures the similarity in habitat suitability between one or more pairs of species using Schoener's D statistics (Schoener 1968). The $D$ value varies from 0 , when species have completely discordant distributions, to 1 , when species have identical distributions.

Additionally, we also calculated the spatial overlap as the proportion of the suitable ranges of two species overlapping in geographical space. Because this analysis requires binary maps depicting suitable (1) and unsuitable habitats (0), its result depends on the threshold value used to convert suitability maps into binary maps. To overcome this issue, we calculated the spatial overlap among species under current and future climate scenarios using binary maps generated with threshold values ranging from 0.05 to 0.6 . This range was employed to represent the variation in the spatial overlapping between species according to the threshold used. Also, the areas showing expansion and/or contraction in spatial interactions among species were quantified using the binary maps.

\section{RESULTS}

\subsection{Model assessment}

The best models selected with AICc varied according to the species (Table S1). For M. $q$. anthidioides and M. q. quadrifasciata, the best model included linear and quadratic feature classes and the default regularization multiplier value (LQ1). For M. scabrella, the selected model included linear, quadratic, hinge, product, and threshold feature classes and the regularization multiplier value of 5 . The selected models for all species had AUC values higher than 0.80, indicating good model performance.

The final model developed for all species included seven variables (Table I). However, the importance of each variable differed depending on the species, indicating a species-specific response to the environmental variables assessed (Table I). For instance, while annual mean temperature was the most important variable for M. scabrella and M. q. anthidioides, for M. q. quadrifasciata precipitation seasonality and precipitation of wettest month were the most relevant. Also, the response curves to the climatic variables evaluated reinforced the differential environmental requirements of each species (Supplementary document).

\subsection{Climate change effects on species distribution}

The models predicted a decrease in climatically suitable areas for all studied species, although the magnitude of this reduction varied depending on species, year and scenarios of climate change (Figure 2). This reduction in climatically suitable area was more severe in 2070 in the scenario RCP 8.5 , when a contraction of $76 \%, 63 \%$ and $54 \%$ was projected for $M$. scabrella, M. $q$. anthidioides and M. q. quadrifasciata, respectively (Figure 2).

Similarly, the centroid analysis demonstrated that both magnitude and direction of the core distribution varied according to the species. While M. q. quadrifasciata shifted the core of its distribution north-eastward, M. q. anthidioides and M. scabrella moved southward (Figure 2). The centroid analysis combined with the climate anomalies analysis indicates that $M . q$. quadrifasciata will change its distribution to regions showing a slight increase in temperature seasonality, precipitation of wettest month, and precipitation seasonality (Fig. S2). On the other hand, M. q. anthidioides and M. scabrella were projected to shift the core of their distribution towards regions with a lower increase in annual mean temperatures and a subtle decrease in temperature seasonality (Fig. S2).

\subsection{Climate change effects on species spatial association}

The contrast between Schoener's $D$ obtained for the present with those estimated for future projections revealed a considerable reduction in spatial overlap between the M. scabrella and the two stingless bees in all years and scenarios of climate change evaluated. The most pronounced 
Table I.. Percent contribution of predictor for the final models developed for each species.

\begin{tabular}{llll}
\hline Predictors & M. scabrella & M.q. anthidioides & M.q. quadrifasciata \\
\hline Elevation & 2.3 & 2.1 & 8.7 \\
Annual mean temperature & 70.5 & 53.9 & 5.0 \\
Temperature seasonality & 4.4 & 6.2 & 25.6 \\
Maximum temperature of warmest month & - & - & 6.3 \\
Minimum temperature of coldest month & - & - & - \\
Temperature annual range & 15.8 & 7.7 & 0.8 \\
Annual precipitation & 0.9 & 3.4 & - \\
Precipitation of wettest month & 2.3 & 18.7 & 30.6 \\
Precipitation of driest month & - & - & - \\
Precipitation seasonality & 3.8 & 7.9 & 22.9 \\
\hline
\end{tabular}

reduction was obtained for 2070 in the scenario RCP 8.5 for all interactions (Figure 3). Similarly, although the proportion of overlapped area varied according to the threshold used, it was always lower in the projected future climate scenarios when compared with the present (Figure 3). The spatial mismatch varied according to the threshold used for M. q. quadrifasciata and was more pronounced when lower threshold values were used to convert suitability maps into binary maps. By contrast, for M. q. anthidioides the spatial mismatch was independent on the threshold used.

The current spatial association between the stingless bees and M. scabrella was estimated predominantly in southern and south-eastern Brazil within the Atlantic Forest domain (Figure 4). Under current climate conditions, the spatial association between bracatinga (MSST $=0.3133)$ and the meliponids $M$. q. anthidioides $(\mathrm{MSST}=0.3547)$ and M.q. quadrifasciata (MSST $=0.4054$ ) was estimated in $21.5 \%$ and $13.1 \%$, respectively. A considerable reduction in spatial association was projected for all associations between bracatinga and the stingless bees (Figure 4). Although this reduction was more pronounced in 2070 in the RCP 8.5 scenario, our models projected losses of up to $71.4 \%$ in the spatial association between M. scabrella and M. q. quadrifasciata in 2050 in the RCP 4.5 scenario. According to projections, most of the remaining climatically suitable areas for the co-occurrence of bracatinga and the stingless bees are in the south-eastern range of their current distribution (Figure 4).

\section{DISCUSSION}

Future climate conditions projected for the twenty-first century suggest drastic changes in species distribution patterns (Warren et al. 2013). In fact, some studies have pointed out that biological responses to current Earth's climate conditions are already measurable in a global scale (Pecl et al. 2017). Since the mid-2000s, several studies were carried out to predict the effects of climate change on species distribution (Erhlén and Morris 2015), but comparatively few were conducted on species spatial association (Schweiger et al. 2008; Schleuning et al. 2016).

Bracatinga is a pioneer species that plays an important role in the ecological succession in the Atlantic Forest (Siminski and Mazuchowski 2014; Citadini-Zanette et al. 2017). After an environmental disturbance, this species develops favouring soil microorganisms due to the large deposition of litter and the symbiotic association with nitrogen-fixing bacteria, providing the environmental conditions for the growth of other secondary species in the initial steps of forest restoration (Citadini-Zanette et al. 2017). Although this species does not depend on specialized pollinators (Sobierajski et al. 2006), winter flowering may constrain the number of pollinators for a species commonly distributed in colder regions, such as the case of bracatinga. Despite the little information about its pollinators, the meliponids $M$. q. anthidioides and M. $q$. quadrifasciata were often cited as important visitors and pollinators of bracatinga (Catharino et al. 


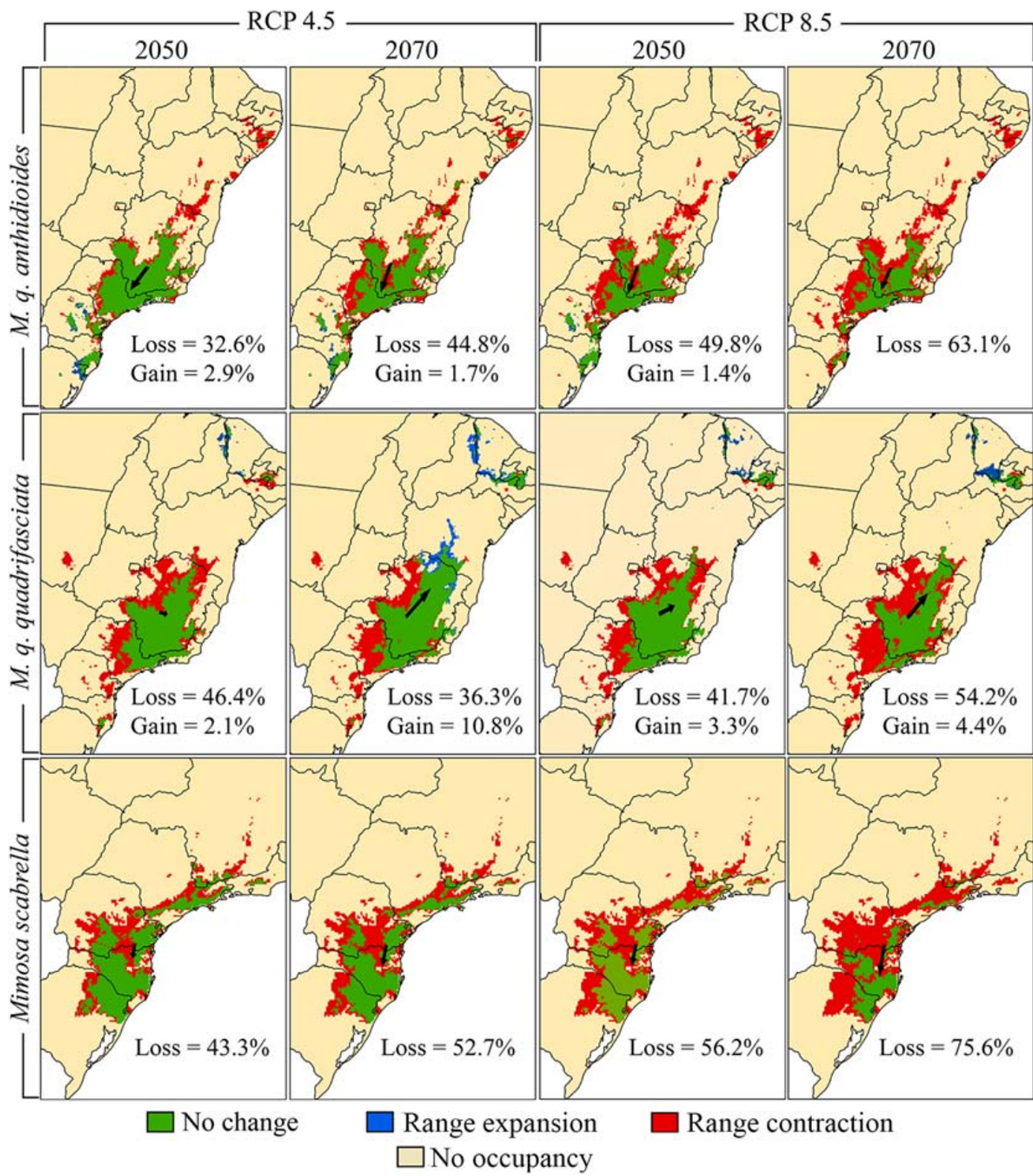

Figure 2. Distribution shifts of Mimosa scabrella and the singles bees Melipona quadrifasciata anthidioides and Melipona quadrifasciata quadrifasciata in different years and climate change scenarios. The arrows indicate the magnitude and direction of the distribution change.

1982; Ramalho et al. 1989; Sobierajski et al. 2006; Oliveira-Abreu et al. 2014; Nascimento et al. 2015). The impact of climate change on these species may have consequences for their spatial association, potentially influencing the regeneration of bracatinga and their role on ecological succession.
Our models revealed species-specific responses to climate change and a drastic reduction in the spatial association between bracatinga and stingless bees. The specific response to climate change in the studied species was clearly demonstrated by the centroid analysis showing that both 

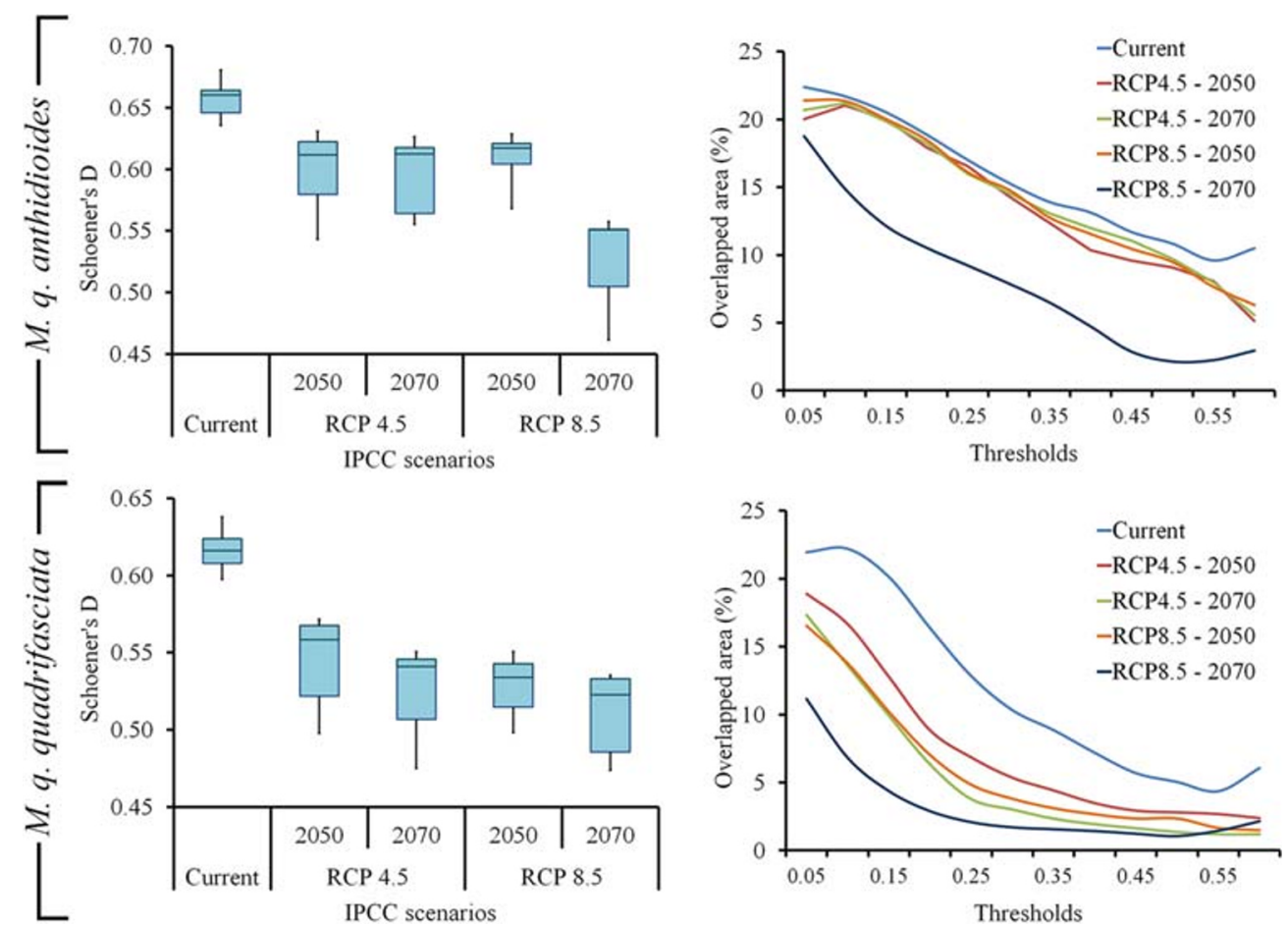

Figure 3. Niche and spatial overlap for the interaction between Mimosa scabrella and the stingless bees Melipona quadrifasciata anthidioides and Melipona quadrifasciata quadrifasciata. Niche overlap analysis measured the similarity in the habitat suitability between pairs of species. The niche overlap was calculated for each of the five General Circulation Models used in this study. Spatial overlap is the proportion of the suitable ranges of two species that overlaps in the geographical space.

magnitude and direction of distribution shifts varied according to the species. For example, discordant range shifts projected between $M$. $q$. quadrifasciata and $M$. scabrella resulted in losses of up to $71.4 \%$ in spatial association even under optimistic climate change scenarios (RCP 4.5). These losses were even more prominent in the RCP 8.5 scenario in 2070, when the models projected a reduction of $94.4 \%$ in these species co-occurrence.

Fossil records indicate that biotic interactions varied widely across time and that temperature played a major role in these changes mainly due to extinctions and shifts in species distribution and abundance (Blois et al. 2013). For example, the rapid warming and ocean acidification that occurred in the Permian-Triassic probably lead to the mass extinction of a large proportion of marine and terrestrial taxa (Chen and Benton 2012; Payne and Clapham 2012). Nowadays, in addition to climate change, anthropogenic impacts such as habitat loss and/or fragmentation may cause local extinctions and intensify changes in species distribution, which may have severe impacts on biotic interactions. This is a serious threat for the study species, as they occur in the Brazilian Atlantic Forest, a highly threatened biome that currently has only $11.3 \%$ of its original coverage (Ribeiro et al. 2009). The deforestation that began in the nineteenth century mainly as a result of urbanization continues to the present due to agriculture expansion (Tabarelli et al. 2010). Although M. scabrella responds well to habitat disturbance, the stingless bees are particularly vulnerable due to their susceptibility to commonly used pesticides (Del Sarto et al. 2014; Tomé et al. 2015). Therefore, the reduction in spatial association between plants and stingless bees may be even more pronounced than predicted by our models. 


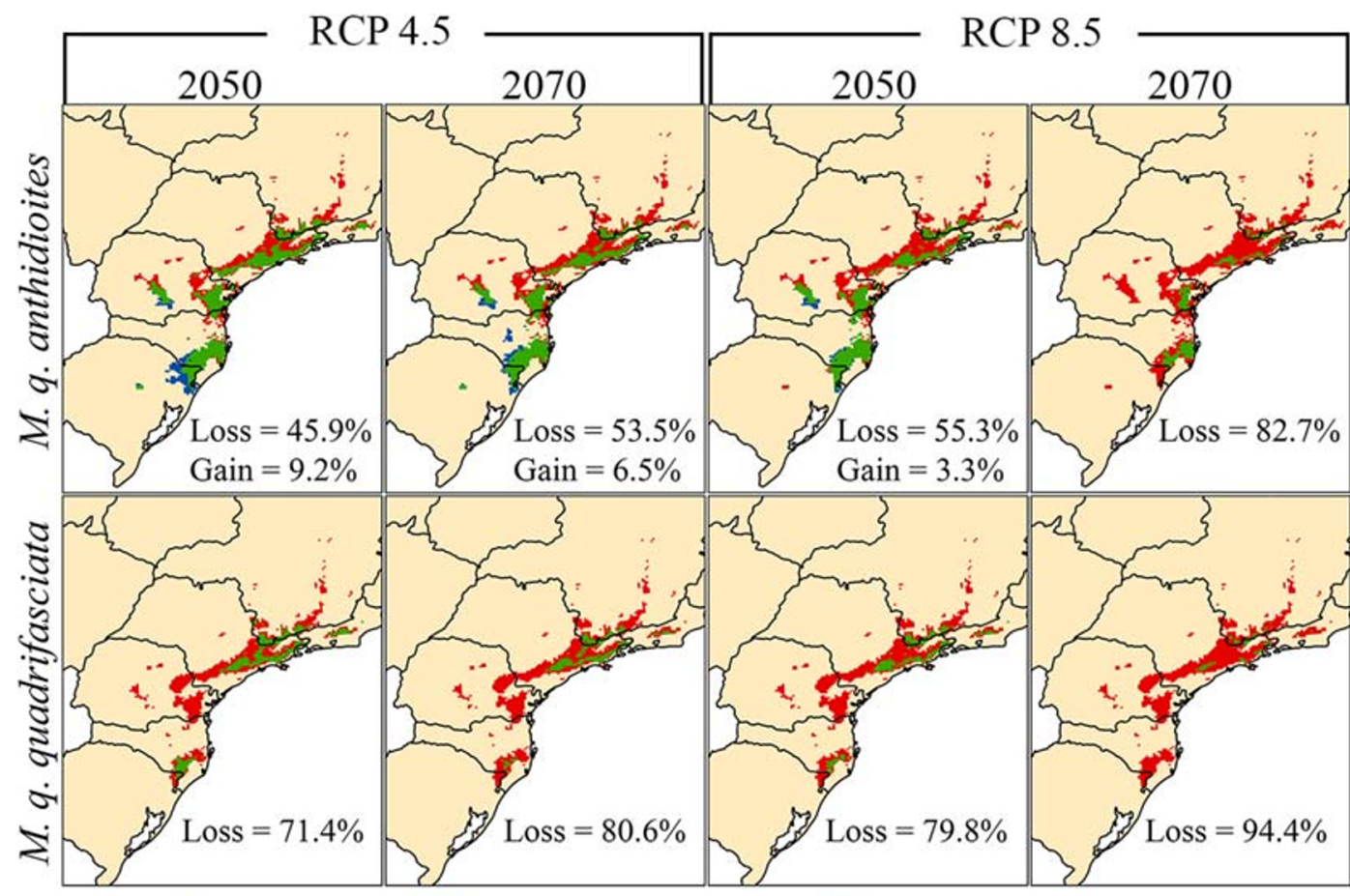

$\square$ No change $\square$ Interaction expansion $\square$ Interaction retraction

$\square$ Area without interaction

Figure 4. Maps depicting regions with expansion and/or contraction in the spatial interaction between Mimosa scabrella and the stingless bees Melipona quadrifasciata anthidioides and Melipona quadrifasciata quadrifasciata.

In this study we assessed the effects of climate change on species spatial association assuming an unlimited dispersal, such that the entire projected climatically suitable regions denote the actual future distribution. In fact, our models indicated that some regions predicted as currently climatically unsuitable may become suitable in the future for both stingless bees. As a consequence, an expansion in spatial association of up to $9.2 \%$ was projected for the interaction between $M . q$. anthidioides and M. scabrella in the southern part of their distributions. These projections can be considered optimistic because species dispersal across the regions predicted as suitable is uncertain and may be constrained by several factors, including land cover or other difficulties inherent to each species (Harsch et al. 2017; Bates et al. 2011; Cariveau et al. 2013; Jha and Kremen 2013).

Despite the predictions indicating a drastic reduction in the spatial association between bracatinga and the stingless bees in the coming years, local extinctions can occur with a substantial delay following habitat degradation (Kuussari et al. 2009). This extinction debt depends on several factors related to species life history traits, the time since habitat was altered and the nature of the alteration (Kuussari et al. 2009). In this context, it is unlikely that sympatric species with different life history traits like the ones studied here will track climate change at the same rate (Schweiger et al. 2008; Devictor et al. 2012). Evidences suggest that delayed extinctions are more likely to occur in long-lived species with low turnover rates compared with short-lived species with high turnover rates (Vellend et al. 2006; Kuussari et al. 2009; Krauuss et al. 2010; GonzálesVaro et al. 2015). The stingless bees have comparatively short generation times, which may favour faster evolutionary responses to selective pressures induced by climate change (Thomas et al. 2010; Catullo et al. 2019). As a pioneer species, bracatinga 
is considered a short-lived species that lives up to 25 years (Siminski and Mazuchowski 2014). Therefore, despite the model predictions indicating a reduction in the spatial association between M. scabrella and the stingless bees, this loss may delay due to local extinction debt.

In summary, this study integrated ENMs and GIS analysis to quantify the effects of climate change on the spatial association between bracatinga and the stingless bees $M$. $q$. anthidioides and M. q. quadrifasciata. Our models projected that the species-specific response to climate change will result in different range shifts, leading to a drastic reduction in the spatial association among species.

\section{ACKNOWLEDGEMENTS}

The authors thank Alexandre ten Caten for allowing the use of the software ArcGIS 10.2.

\section{AUTHOR CONTRIBUTIONS}

CAM, VPL and CRS conceived the research, developed the models and analysed the results. CAM wrote the manuscript.

\section{COMPLIANCE WITH ETHICAL STANDARDS}

Conflict of interest The authors declare that they have no conflicts of interest.

Le changement climatique peut affecter les associations spatiales entre les abeilles sans dard et Mimosa scabrella dans la forêt atlantique brésilienne.

Interaction biotique / modélisation de niche écologique / Melipona / pollinisation / association spatiale.

Der Klimawandel kann die räumlichen Assoziationen zwischen stachellosen Bienen und Mimosa scabrella im brasilianischen Regenwald beeinflussen.

Biotische Interaktionen / ökologisches Nischenmodel / Melipona / Bestäubung / räumliche Assoziation.

\section{REFERENCES}

Araújo E.D., Costa M., Chaud-Netto J., Fowler H.G. (2004) Body size and flight distance in stingless bees (Hymenoptera: Meliponini): Inference of flight range and possible ecological implications. Braz J Biol 64, 563-568

Bates A.E., Pecl G.T., Frusher S., Hobday A.J., Wernberg T., Smale D.A. et al (2014) Defining and observing stages of climate-mediated range shifts in marine systems. Glob Environ Chang 26, 27-28

Bates A.J., Sadler J.P., Fairbrass A.J., Falk S.J., Hale J.D., Matthews T.J. (2011) Changing bee and hoverfly pollinator assemblages along an urban-rural gradient. PLoS One 6, e23459

Bispo dos Santos S.A., Roselino A.C., Hrncir M., Bego L.R. (2009) Pollination of tomatoes by stingless bees Melipona quadrifasciata and the honey bee Apis melifera (Hymenoptera: Apidae). Genet Mol Res 8, $751-757$

Blois J.L., Zarnetske P.L., Fitzpatrick M.C., Finnegan S.S. (2013) Climate change and the past, present, and future of biotic interactions. Science 341, 499-504

Brown L., Bennet J., French C.M. (2017) SDMtoolbox: the next generation python-based GIS toolkit for landscape genetic, biogeographic and species distribution model analyses. PeerJ. 5, e4095

Cariveau D.P., Williams N.M., Benjamin F.E., Winfree R. (2013) Response diversity to land use occurs but does not consistently stabilise ecosystem services provided by native pollinators. Ecol Lett 16, 903-911

Catharino E.L.M., Crestana C.S.M., Kageyama P.Y. (1982) Biologia floral da bracatinga (Mimosa scabrella Benth.). Silvicultura em São Paulo 16, 525-531

Catullo R.A., Llewelyn J., Phillips B.L., Moritz C.C. (2019) The potential for rapid evolution under anthropogenic climate change. Curr Biol 29, 996-1007

Chen Z.-Q., Benton M.J. (2012) The timing and pattern of biotic recovery following the end-Permian mass extinction. Nat Geosci 5, 375-383

Citadini-Zanette V., Negrelle R.R.B., Leal-Filho L.S., Remor R., Elias G.A., Santos R. (2017) Mimosa scabrella Benth. (Fabaceae) enhances the restoration in coal mining areas in the Atlantic rainforest. Cerne 23, 103-114

Del Sarto M.C.L., Oliveira E.E., Guedes R.N.C., Campos L.A.O. (2014) Differential insecticide susceptibility of the Neotropical stingless bee Melipona quadrifasciata and the honey bee Apis mellifera. Apidologie 45, 626-636

Devictor V., van Swaay C., Brereton T., Brotons L., Chamberlain D. et al (2012) Differences in the climatic debts of birds and butterflies at a continental scale. Nat Clim Chang 2, 121-123 
Elith J., Kearney M., Phillips S. (2010) The art of modelling range-shifting species. Methods Ecol Evol 1, 330-342

Erhlén J., Morris W. (2015) Predicting changes in the distribution and abundance of species under environmental change. Ecol Lett 18, 303-314

Fielding A.H., Bell J.F. (1997) A review of methods for the assessment of prediction errors in conservation presence/absence models. Environ Conserv 24, 38-49

Flora do Brasil. (2018). Jardim Botânico do Rio de Janeiro [online] http://floradobrasil.jbrj.gov.br ().

Fourcade Y., Engler J.O., Rödder D., Secondi J. (2014) Mapping species distributions with Maxent using a geographically biased sample of presence data: a performance assessment of methods for correcting sampling bias. PLoS One 9, e97122

Gonzáles-Varo J.P., Albaladejo R.G., Aizen M.A., Arroyo J., Aparicio A. (2015) Extinction debt of a common shrub in a fragmented landscape. J Appl Ecol 52, 580589

Harrington R., Woiwod I., Sparks I. (1999) Climate change and trophic interactions. Tr Ecol Evol 14, 146-150

Harsch M.A., Phillips A., Zhou Y., Leung M.R., Rinnan D.S., Kot M. (2017) Moving forward: insights and applications of moving-habitat models for climate change ecology. J Ecol 105, 1169-1181

Hegland S.J., Nielsen A., Lázaro A., Bjerknes A.L., Totland O. (2009) How does climate warming affect plant-pollinator interactions? Ecol Lett 12, 184-195

Hijmans R.J., Cameron S.E., Parra J.L., Jones P.G., Jarvis A. (2005) Very high resolution interpolated climate surfaces for global and areas. Int J Climatol 25, 1965-1978

Hill M.P., Terblanche J.S. (2014) Niche overlap of congeneric invaders supports a single-species hypothesis and provides insight into future invasion risk: implications for global management of the Bactrocera dorsalis complex. PLoS One 9, e90121

I.P.C.C (2014) Climate Change 2014: the Physical Science Basis. Working Group I Contribution to the Fifth Assessment Report of the Intergovernmental Panel on Climate Change. Cambridge University Press, Cambridge

Jha S., Kremen C. (2013) Urban land use limits regional bumble bee gene flow. Mol Ecol 22, 2483-2495

Klein A.M., Vaissiere B.E., Cane J.H., Steffan-Dewenter I., Cunningham S.A., Kremen C., Tscharntke T. (2007) Importance of pollinators in changing landscapes for world crops. P R Soc London 274, 303-313

Knouft J.H., Flicklin D.L. (2017) The potential impact of climate change on biodiversity in flowing freshwater systems. Annu Rev Ecol Evol Syst 48, 111-133

Krauuss J., Bommarco R., Guardiola M., Heikkinen R.K., Helm A. et al (2010) Habitat fragmentation causes immediate and time delayed biodiversity loss at different trophic levels. Ecol Lett 13, 507-605

Kuussari, M., Bommarco, R., Heikkinen, Helm, A., Krauss, J., et al. (2009) Extinction debt: a challenge for biodiversity conservation. Tr Ecol Evol 24, 567571.

Lautenbach S., Seppelt R., Liebscher J., Dormann C.F. (2012) Spatial and temporal trends of global pollination benefit. PLoS One 7, e35954.615-e35954.618

Lunelli N.P., Ramos M.A., Oliveira Júnior C.J.F. (2016) Do gender and age influence agroforestry farmers' knowledge of tree species uses in an area of the Atlantic Forest, Brazil? Acta Bot Bras 30, 667-682

Luz C.F.P., Junior G.L.B., Fonseca R.L.S., Sousa P.R. (2010) Comparative pollen preferences by africanized honeybees Apis mellifera L. of two colonies in Pará de Minas, Minas Gerais. Brazil An Acad Bras Ciênc 82, 293-304

Mayor, S.J., Guralnick, R.P., Tingley, Otegui, J., Withey, J.C., et al. (2017) Increasing phenological asynchrony between spring green-up and arrival of migratory birds. Sci Rep 7, 1902.

Meinshausen M., Smith S.J., Calvin K., Danuel J.S., Kainuma M.L.T. et al (2011) The RCP greenhouse gas concentrations and their extensions from 1765 to 2300. Clim Chang 109, 213-241

Memmot J., Craze P.G., Waser N.M., Price M.V. (2007) Global warming and the disruption of plant-pollinator interactions. Ecol Lett 10, 710-717

Merow X., Smith M.J., Silander J.A. Jr. (2013) A practical guide to MaxEnt for modelling species' distributions: what it does, and why inputs and settings matter. Ecography 36, 1-12

Morales N.S., Fernández I.C., Baca-Gonzáles V. (2017) MaxEnt's parameter configuration and small samples: are we paying attention to recommendations: A systematic review. PeerJ 5, e3093

Nascimento A.S., Marchini L.C., Carvalho C.A.L., Araújo D.F.D., Silveira T.A. (2015) Pollen spectrum of stingless bees honey (Hymenoptera: Apidae), Paraná state. Brazil J Entomol Zool Stud 3, 290-296

Oliveira-Abreu C., Hilário S.D., Luz C.F.P., Alves-dosSantos I. (2014) Pollen and nectar foraging Melipona quadrifasciata anthidioides Lepeletier (Hymenoptera: Apidae: Meliponini) in natural habitat. Sociobiology 61 , 441-448

Ollerton J., Winfree R., Tarrant S. (2011) How many flowers are pollinated by animals? Oikos 120, 321326

Payne J.L., Clapham M.E. (2012) End-Permian mass extinction in the oceans: an ancient analog for the twentyfirst century? Annu Rev Earth Planet Sci 40, 89-111

Pecl G.T., Araújo M.B., Bell J.D., Blancherd J., Bonebrake T.C. et al (2017) Biodiversity redistribution under climate change: impacts on ecosystem and human wellbeing. Science, 355-eaai9214

Phillips S.J., Anderson R.P., Schapire R.E. (2006) Maximum entropy modelling of species geographic distributions. Ecol Model 190, 231-259

Radosavljevic A., Anderson R.P. (2014) Making better Maxent models of species distribution: complexity, overfitting and evaluation. J Biogeogr 41, 629-643 
Ramalho M., Kleinert-Giovannini A., Imperatriz-Fonseca V.L. (1989) Utilization of floral resources by species of Melipona (Apidae, Meliponinae): floral preferences. Apidologie 20, 185-195

Ribeiro M.C., Metzger J.P., Martensen A.C., Ponzoni F.J., Hirota M.M. (2009) The Brazilian Atlantic Forest: how much is left, and how is the remaining forest distributed: implications for conservation. Biol Conserv 142, 1141-1153

Rodda G.H., Jarnevich C.S., Reed R.M. (2011) Challenges in identifying sites climatically matched to the native ranges of animal invaders. PLoS One 6, e14670

Schleuning M., Fründ J., Schweiger O. et al (2016) Ecological networks are more sensitive to plant than to animal extinction under climate change. Nat Commun 7,13965

Schoener T.W. (1968) Anolis lizards of Bimini: resource partitioning in a complex fauna. Ecology 49, 704-726

Schweiger O., Stelle J., Kudrna O., Klotz S., Kühn I. (2008) Climate change can cause spatial mismatch of trophically interacting species. Ecology 89, 3472-3479

Siminski A., Mazuchowski J.Z. (2014) Caracterização da espécie. In Mazukowski J.Z., Rech T.D., Toresan L. (Eds.), Bracatinga, Mimosa scabrella Benthan: Cultivo, manejo e usos da espécie. Epagri 365p

Slaa E.J., Sanchez-Chaves L.A., Malagodi-Braga K.S., Hofstede F.E. (2006) Stingless bees in applied pollination: practice and perspectives. Apidologie 37, 293315

Sobierajski G.R., Kageyama P.Y., Sebbenn A.M. (2006) Estimates of genetic parameters in Mimosa scabrella populations by random and mixed reproduction models. Crop Breed Appl Biot 6, 47-54
Tabarelli M., Aguiar A.V., Ribeiro M.C., Metzger J.P., Peres C.A. (2010) Prospects for biodiversity conservation in the Atlantic Forest: lessons from aging humanmodified landscapes. Biol Conserv 143, 2328-2340

Thomas J.A., Welch J.J., Lanfear R., Bromham L. (2010) A generation time effect on the rate of molecular evolution in invertebrates. Mol Biol Evol 27, 1173-1180

Tomé H.V.V., Barbosa W.F., Martins G.F., Guedes R.N.C. (2015) Spinosad in the native stingless bee Melipona quadrifasciata: regrettable non-target toxicity of a bioinsecticide. Chemosphere 124, 103-109

Vellend M., Verheyem K., Jacquemyn H., Kilb A., Van Calster H., Peterken G., Hermy M. (2006) Extinction debt of forest plants persists for more than a century following habitat fragmentation. Ecology 87, 542-548

Warren R., VanDerWal J., Proce J. et al (2013) Quantifying the benefit of early climate change mitigation in avoiding biodiversity loss. Nat Clim Chang 3, 678683

Williams S.E., Shoo L.P., Isaac J.L., Hoffmann A.A., Langham G. (2008) Towards an integrated framework for assessing the vulnerability of species to climate change. PLoS Biol 6, 2621-2626

Zwiener V.P., Lira-Noriega A., Grady C.J., Padial A.A., Vitule J.R.S. (2018) Climate change as a driver of biotic homogenization of woody plants in the Atlantic Forest. Glob Ecol Biogeogr 27, 298-309

Publisher's note Springer Nature remains neutral with regard to jurisdictional claims in published maps and institutional affiliations. 